\title{
Colonialism and Environment: A Postcolonial Eco-critical Approach towards Dhruv Bhatt's Oceanside Blues
}

\author{
Nisha Paliwal ${ }^{1}$ \\ ${ }^{1}$ M.A. English, Central University of Rajasthan, India
}

\begin{tabular}{|c|c|}
\hline Article Info & Abstract \\
\hline $\begin{array}{l}\text { Article history: } \\
\text { Received } 00 \text { December } 00 \\
\text { Received in revised form } 00 \\
\text { January } 00 \\
\text { Accepted } 00 \text { February } 00\end{array}$ & $\begin{array}{l}\text { Purpose: The present paper analyses the role of nature in the lives of the } \\
\text { tribals while exploring their indigenous eco-customs and traditions that } \\
\text { have helped in sustaining their eco-centric approach to life. It also explores } \\
\text { the culture-nature dialectic that surfaces the long-lasting conflict between } \\
\text { tradition and modernity through a distinctive tribal perspective. }\end{array}$ \\
\hline $\begin{array}{l}\text { Keywords: } \\
\text { Colonialism, Tribal, Nature, } \\
\text { Tradition, Modernity. } \\
\text { Paper Type : } \\
\text { Research Article }\end{array}$ & $\begin{array}{l}\text { Methodology/ Approach: Postcolonial ecocritical approach.. } \\
\text { Findings: The paper analyzes Oceanside Blues (2001) by Dhruv Bhatt, a } \\
\text { Gujarati writer, from an eco-critical perspective while exploring the } \\
\text { representation of tribal eco sensibilities and analyzing their eco-ethical } \\
\text { imports. The narratives along with sending a lucid message for the survival } \\
\text { of ecology, urge the human race to rekindle its communion with nature. }\end{array}$ \\
\hline $\begin{array}{l}\text { Corresponding Author: } \\
\text { Nisha Paliwal } \\
\text { Email: } \\
\text { nishoo1997@gmail.com }\end{array}$ & $\begin{array}{l}\text { Conclusion: The novel in itself is a piece of resistance against the colonial } \\
\text { activities that harm the environment as well as the tribal people by seizing } \\
\text { their land on their preconceived notion of growth and development that } \\
\text { contradicts their cultural values. Nature protests in its own ways like the sea } \\
\text { protesting against environmental destruction in the form of a tornado in the } \\
\text { region. }\end{array}$ \\
\hline
\end{tabular}

\section{Introduction}

The politics of colonization and the attached greed of capitalists in the name of civilization have resulted in dire impacts towards the environment and the relationship between man and nature. The materialistic civilization, introduced by the Occidentals and which persists in the form of global imperialism, has led man towards the path to butcher mother earth to plunder resources for his benefit. The exploitation of tribal land in the name of civilization is not a recent phenomenon, it is a long-lived tradition passed down by the colonizers as the fiction of national progress. The notions of civilization, progress and development modelled on the dictums of western thought are also deconstructed within the framework of tribal ecological consciousness. Ecocriticism attempts to transcend the duality of art and life, human and the natural, and explore the interconnections between them. In this respect, ecocriticism takes into account varied literary, ecological and philosophical perspectives.

Oceanside Blues is a Gujarati novel written by Dhruv Bhatt and translated into English by Vinod Meghani. Set in the coastal region of Saurashtra, it is an account of a civil engineer who has been assigned the task of surveying the land to establish a chemical factory in the tribal region. Dhruv Bhatt has been regarded as a remarkable writer known for establishing a discourse on the current environmental issues faced by the world by 
fictionalizing them and questioning the 'cynical, profit-driven economy'. Numerous environmental issues have been interwoven in the novels of Bhatt, like the conflict between human and wildlife, the encroachment of forest areas and resulting concerns in livelihood and access to the forest for resources to survive, forestry management, illegal mining, ecological imperialism, climate change and ecology etc.

He inherited his eminent love for literature from his parents. His father was a poet and his mother was an avid reader. Throughout his life, Bhatt had been immensely passionate about the wonders of nature which also led him to reform the education in his region by introducing an environmental dimension to education by exposing the children to nature by organizing camps, workshops in the forests, seashores etc. His close connection with nature is reflected in his novels like Samudhrantike, Tatvamasi etc, where he forms a narrative about the lives of people living in the nature abodes that is untouched by the greedy, profit-driven capitalistic agencies and represents a realistic picture of locals where along with the characters, nature as well takes the form of a separate being and exists throughout the narrative. In the novel, Oceanside Blues, Bhatt builds a narrative around the lives of people living along the seashore, engrossed in their own life and culture oblivious of the world that transcends them. Giving a vivid description of the natural region, Bhatt sets a magnificent ambience to the novel. However, the interference of the humans and capitalist agencies is dealt with equal empathy forcing the reader to reflect on the issues that concern the people as well as nature. Coming from a modern and developed city, the narrator finds himself as a misfit who fails to understand the lifestyle and culture of the inhabitants of the region. He feels like he has been 'banished' to 'an outlandish exile'.

\section{Methodology/Approach}

The approach employed in the textual analysis is postcolonial ecocritical approach. The paper analyzes Oceanside Blues (2001) by Dhruv Bhatt, a Gujarati writer, from an ecocritical perspective while exploring the representation of tribal eco-sensibilities and analyzing their eco-ethical imports.

\section{Analysis and Results}

\section{Postcolonial Ecocriticism Theory}

Postcolonial Ecocriticism is a theoretical framework used to analyse and understand the colonial activities that are now being undertaken by capitalists, neocolonizers to fuel their profit driven ventures damaging and destroying the environment. With the anthropocentric view of life that stipulates that everything centres around human beings viewing nature as a capitalistic commodity, the foundation of our life with early education in schools begins with the idea that 'man is the best creation of nature' and that 'nature's sole purpose is to serve mankind'. Postcolonial Ecocriticism theory questions this view of life and incorporates the postcolonial as well as ecocritical perspective in order to study the exploitation of environment caused by colonial activities as well as the ways that the subalterns are affected by it. The theory also draws attention to the western-centric approach to view the colonized 
space as 'empty' that is ready to be exploited. It questions the denial of access to resources to the indigenous people in their own land expressing concern about their vanishing knowledge highlighting the sustainability of their lifestyle and cultural practices.

\section{Colonization and Globalization}

For centuries, Colonialism has established a global infrastructure that supports and encourages the developed and rich countries to manipulatively plunder the natural resources from the so called poorer countries. Colonialism and the environment are interconnected and cannot be separated. Colonial practice greatly affects the well being of the environment and threatens the survival of the Indigenous people and their sustainable practices. In an article written by Greta Thunberg along with Luisa Neubauer and Angela Valenzuela titled 'Why we strike again', the link between colonialism and environment has been established. They write -

"the climate crisis is not just about the environment. It is a crisis of human rights, of justice and of political will. Colonial, racist, and patriarchal systems of oppression have created and fuelled it. We need to dismantle them all."

Colonisation and Globalisation, as a process, hold similar ideologies of domination as well as the similar relationship between the suppressor and oppressor. Goods were forcefully introduced and brought into consumption by the colonial powers in the oppressed countries for profit which resulted in the decline of the productivity of the colonized countries. Neocolonization has replaced the practice of colonization today because it seems impossible to impose colonial rules on countries to turn them into colonies, rather than applying force. The powerful west has established imperialism to control and direct the rest of the world. Similarly, globalization creates a global network which helps the west in controlling economy, society, culture etc by transmitting ideas, popular culture, language, industries through 'cultural diffusion'. It is threatening the survival of the indigenous culture and knowledge by homogenizing the indigenous way of living which also puts the environment at risk.

Environmental colonialism began by altering the native ecosystem by exposing them to foreign species, extracting natural resources hugely impacting the environment giving rise to the issues such as global warming, destruction of forests and extinction of native species resulting in the decline of biodiversity etc. These issues are reflected in the novel Oceanside Blues as the tribal people living around the coastal region of Saurashtra not only have to deal with climate change that have destroyed the forests and wildlife but have also caused them to migrate to the cities for menial jobs in order to survive. Whereas, the chemical factory to be established in the region after declaring it as infertile and useless is a symbol of practices of colonization and its view of defining everything from their standard and understanding neglecting the native factors involved. In the current times, the particular topic holds significance due to the rapidly changing climate and environment crisis that the world is going under because the land that is being exploited and the rich indigenous knowledge that is under the threat of being wiped out is the only sustainable way of life that can protect the 
environment. Moreover, the issue isn't only faced by the tribals of Saurashtra rather it is a global problem dealt by all the indigenous population whose culture is on the verge of extinction because of this interference.

\section{Tribal Ecological Consciousness}

The people of the area are interconnected and dependent on their surroundings for all their daily activities. They view nature as an individual living entity that is deeply rooted in all aspects of their life and culture. The sea works as a guide that directs the people walking along the seashore. As Saboor says 'The sea would guide us all the way.' The most significant element of nature that the inhabitants treat as some kind of deity is the sea, the sea appears as a metaphor around which all the activities of the people are involved, it paves the path for people and when infuriated destroys everything that comes in its path. The fishermen, Krishna, believes that we are just puppets in the hand of nature such as the sea that can either let him dive in itself or through him out, the sea will always guide the path and none can go against its wish.

The traditions and festivals of the people also are connected with the sea, after the arrival of the narrator he is unable to sail to the estate bungalow because no sailor is willing to set sail after the akhaatrij because 'after akhaatrij the sea forbids sailing until the full moon after the monsoon when a coconut is offered to the sea. Only then it opens its routes'. The no moon festival expects all the people to take a dip in the sea, everyone gathers around the seashore after a pilgrimage and take a dip as a pretext to come closer to the ocean, the ocean that they worship as a deity and it plays a significant role in their lives, witnessing their happiness and sorrow. The people gather to form a communion with Mother Nature.

Even the passage of time is indicated by the nature, the narrator says-

"All the indicators of the passage of time except dawn and dusk were meaningless here. The inhabitants scattered over this wilderness called the duration between two rainy seasons a year and that between two dawns a day. They did not complicate their lives by naming days of the week and counting dates of the month."

The inhabitants spared themselves the complicated markers of time that are followed by the world instead relating it to daily events. Adapting to these indicators of time, the narrator confides that

"Living in this atmosphere, I too have begun to do the same. It was dawn when a face could be seen clearly. Morning was the time to breakfast or when herds went out grazing in the pastures. Noon was the lunch hour, and it was dusk when the sky turned hazy by the dust kicked up by the hooves of the cattle hurrying home after daylong grazing. Godhooli! Cow-dust hour! Today I learnt that after-dusk darkness came at the gong hour when the villagers of Vishno's village congregated at the local shrine or temple for aarati, a tribute to the deities; village-folks tired after daylong toilinig rested their aching limbs by sitting down at the temple for the dusk prayer. Finally, when total peace settled on the earth, it was called the night." 
The characters in the novel are the preserver of nature. They consider the sea a superior entity that must not be made angry to avoid any repercussions. Nature comes alive and has been frequently personified, a sage living in isolation talks with his surroundings. On the narrator's presumption of his lifestyle as 'lonesome and monotonous', he says 'Look at the ocean. I've never seen it in the same form a second time...I'm not alone here...There's the ocean, the sand, the thorny thickets and above everything else, the stars glittering every night. I've formed a habit of conversing with them and I am afraid a single life is too short a duration to talk to them all.' The sage represents an excellent example of the relationship between man and nature existing without any greed or self interest. Moreover, when the narrator confess to the sage about feeling guilty of the job he has been assigned that will eventually pollute the land, the sage tells him that his 'existence in the universal destiny is no more important than these pebbles on the seashore', the sage believes that we have confined the meaning of nature to be very limited and 'there was a time when earth did not exist. Then too nature existed...Nature is always absolute, and unconfined.'

Because of being confined to the land they occupy, the Indigenous people are dependent on the forest for resources for their survival, they forage the forest for food and medicine considering the jungle as the gift of God. However, during the recent times, the forests have been encroached by the Forest Department limiting the access of the tribals in their own area. This also threatens their survival. In the novel, due to the change in climate caused by the human activities, the area has been struck by famines one after another that have destroyed the region as well as the forest. Noor Bhai, a native, who has been deployed as a forest guard in the area is being assigned to protect the forest. However, we learn that 'in deep jungle, timber's felled and stolen by cartloads' possibly due to corruption that allows the capitalistic agencies to flourish. Due to the forest preservation policies that are inclined towards capitalistic motives, the indigenous people are marginalized and driven away from their own land by bordering forest areas for preservation. In the novel, the people are not allowed to take resources from the forests. A group of youngsters accompanied by Aval is caught by the narrator carrying twigs and shrubs. She explains: 'in the entire region there's no firewood except in he thickets. When the boys'd reach home with what you call wood, their mothers'd ignite the stoves and bake them a loaf' showing the intensity of troubles that they people have to go through because of these policies.

\section{Eurocentric Approach}

The West forcefully imposed their notion of Western environmentalism on the developing countries, colonizing the environment as well. They were forcefully exposed to the ecology of the colonizers that were introduced in the colonies. This ecological imperialism has had a dire impact on the native ecosystem destabilizing their sustainable culture. With their own definition of what is productive and what is not, the tribal land that is flourishing with its own native qualities is seen as barren, unproductive and 'empty lands' from the eurocentric point of view as it doesn't fulfil the western criteria of productivity. With the same view, the narrator has embarked on the path to propose the establishment of a factory fuming with poisonous chemicals in the region that he considers to be 'barren of 
trees, infertile and sparsely populated'. With this neo-colonial and western-centric attitude, the rich indigenous culture and knowledge is being wiped up being replaced by a homogenous culture followed by the world.

The narrator of the novel is the embodiment of a neo-colonized youth with a notion of cultural backwardness. The civil engineer embodies the ideas that are generally perceived by the colonizers about the culture and people that they fail to understand. He feels as if he has been banished to an outlandish exile into a 'land of legends born of beliefs and faith' that he considers insane. The contrast between the character of Noor-Bhai and Nirmal is a blatant example of the difference between westernized knowledge and the indigenous lifestyle of living in the lap of nature. Noor-Bhai is an ardent lover of nature who has helped revive the forest by planting babul trees in the 'salty, barren marshland'. He frequently reminisces about the lush green forest he remembers from his childhood prospering with different species of birds. Due to the change in climate resulting in a decrease in rainfall, the soil has turned salty causing famine in the region. Noor-Bhai recounts:

'Saaheb, there was a time when the entire terrain breathed...They say that during the time of my abba-jaan there was a forest here... What remains of the forest is a Banyan tree in Khera and sparse orchards around Vaaraaroop. All else is destroyed. Famines, one after another, have mercilessly ravaged the region. The soil has turned all salty. This thorny thicket is a bounty of the Allah.'

The disappearance of forest has also resulted in the vanishing of species of birds and animals specific to the region, Noor-Bhai experiences a kind of affinity with nature, admiring the birds seeing them as a gift of God that he is trying to preserve and protect. Witnessing Noor-Bhai's love for birds, the narrator is taken back into his childhood narrating an incident about his experience with his uncle's friend, Nirmal, who was an ornithologist. Nirmal was engaged in research on the behaviour patterns of eagles, he observed them and analysed his recordings in a university lab. The narrator, on his visit to his lab, witnessed two weak and feeble eagles kept in separate cages. They were being starved in order to understand their behaviour in such a circumstance when placed with a cat and to observe how long they endure hunger and thirst. Western-centric approach to education promotes such divorce from nature where one studies it as an outsider rather than a part of it. The willingness to brutally torture a being in order to understand their behaviour showcases the disconnection between man and nature. The narrator understands this and comments that 'I felt that the entire system needed a complete change. Education should mean teaching to love nature. A system that can produce many more Noor-bhaais should be evolved'.

Nature is viewed as a property to fulfil the greed of the elite industrialists and capitalists. The chemical factory being planned in the area represents the colonial culture to exploit the land of the tribals. With the rise in industrial activities, global warming has also escalated giving birth to a number of problems such as pollution, climate change that directly or indirectly affect the majority of the indigenous population. The decrease in rainfall in the region has caused many people to migrate to the nearby town in search of work after failing to yield enough crop for their survival. The characters such as Saboor, Shamji Mukhi migrate 
to south Gujarat with the arrival of summer and only return after the first rainfall. On their way, they give away their cattle to anyone who can feed them and fetch them back when they return. The dire poverty and their desperate to survive drag them out of their own land to work as labourers with low wages. The preservers of nature are made to exploit it by indulging in activities such as mining, factory work etc in order to have a livelihood.

\section{Resistance}

The notion to tag everything that the colonizers consider as barren and unproductive in order to make profit out of that land is challenged by characters such as Noor-Bhai and Saboor. Noor-Bhai revived a forest out of the leftover marshlands that was considered barren, his utmost dedication, hardwork and gratitude for nature makes it possible to reverse the ecological damage that was caused by climate change. Saboor, on the other hand, turns a twothree acre land of granite stone given to him into gold. Saboor, a landless labourer, acquires the land and with the help of his wife and his fruitful attempts and dedication cultivates saplings of mango, coconut, chikoo and pomegranate. Saboor reveals -

"From day land was given to me, both of us began swinging our axe and prising rock, morning till night...at first we bore holes in the rock just as they did when digging a well. Then etched out troughs deep as a man and wide as two bedsheets and stuffed them with cartloads of manure and soil."

A land that would have otherwise been declared as barren and empty to establish industries and factories harming the environment was turned into something beautiful that united us with nature. Saboor challenges this postcolonial notion of discarding land in terms of their notion of so-called productivity.

The novel in itself is a piece of resistance against the colonial activities that are harming the environment as well as the tribal people by seizing their land on their preconceived notion of growth and development that contradicts their cultural values. Nature protests in its own ways like the sea protesting against environmental destruction in the form of a tornado in the region.

\section{Conclusion}

Through the novel, the author tries to contemplate a balance in the man and nature relationship delineating that each creature is equally important; the author condemns the beliefs of humans of being superior to other creatures as there is a dependence of humans on nature for their survival whereas nature is independent. The narrator meets several characters such as Noor-bhai, Krishna, Saboor, Aval, and the sage who teaches him the significance and value of nature around them. In today's time, humans have completely lost the harmony with nature resulting in visible abnormal changes in the climate. We have paved our own way towards destruction by harming the environment. We have repeatedly exploited nature for profit, plundering the indigenous land whereas it is only the traditional indigenous knowledge that can save and restore the environment. 


\section{Conflict of Interest}

None

Funding

None

\section{Work Cited}

Abrams, M. H. A Glossary of Literary Terms, 8th Edition. New Delhi: Thomsan and Wadsworth, 2007. Print.

Bhatt, Dhruv. Trans. Vinod Meghani. Oceanside Blues. New Delhi: Sahitya Akademi, 2001. Print.

Duquette, Kelly. “Environmental Colonialism”. Scholarblogs. Jan 2020. https://scholarblogs.emory.edu/postcolonialstudies/2020/01/21/environmentalcolonialism/\#: :text=Environmental\%20colonialism\%20refers $\% 20$ to $\% 20$ the, able $\% 20$ to $\% 20$ alter\%20native\%20ecosystems.

Kuck, Nathanael. "Anti-colonialism in a Post-Imperial Environment-The Case of Berlin, 191433." Journal of Contemporary History, vol. 49, no.1, 2014, 134-159. https://www.jstor.org/stable/43697292

Huggan, Graham. Tiffin, Helen. Postcolonial Ecocriticism: Literature, Animals, Environment. New York: Routledge. 2009.

Jotva, Vijay V. "An Ecocritical Study of Dhruv Bhatt's Samudrantike”. International Journal of English Language, Literature in Humanities, vol.6. pp. 249-256.

Lange, Matthew, James Mahoney, and Matthias Vom Hau. "Colonialism and development: A comparative analysis of Spanish and British colonies." American Journal of Sociology. Vol.111, no.5,2006, pp. 1412-1462. http://www.jstor.com/stable/10.1086/499510

Neubauer, Luisa. Thunberg, Greta. Valenzuela, Angela. “Why we strike again”. Social Europe. Dec 2019. https://www.socialeurope.eu/why-we-strike-again

Pouchepadass, Jacques. "Colonialism and environment in India: Comparative perspective." Economic and Political Weekly, vol. 30, no. 33,1995,pp.2059-2067. https://www.jstor.org/stable/4403103

Sabee, Olivia. "Ballet as Discourse: Environment, Diversity, and Colonialism in La Source."
Dance
Chronicle,
vol.44,
no.1, 2021,
pp.91-96. https://doi.org/10.1080/01472526.2021.1875970

Whyte, Kyle. "Settler colonialism, ecology, and environmental injustice." Environment and Society, vol. 9, no.1, 2018, 125-144. https://www.jstor.org/stable/10.2307/26879582

Young, Jason C. "The new knowledge politics of digital colonialism." Environment and Planning A: Economy and Space, vol.51, no.7, 2019,pp.1424-1441. http://dx.doi.org/10.1177/0308518X19858998 